\title{
高齢者の選択気温からみた心理生理反応特性 THE CHARACTERISTICS OF PSYCHOLOGICAL AND PHYSIOLOGICAL RESPONSE BY PREFERRED AIR TEMPERATURE OF THE ELDERLY
}

\author{
佐々尚美*, 久保博子**, 磯田憲生 ${ }^{* * *}$ \\ Naomi SASSA, Hiroko KUBO and Norio ISODA
}

\begin{abstract}
The purpose of this study is to investigate the individual variations of preferred air temperature and the characteristics of psychological and physiological response by preferred air temperature of the elderly. The subjects who were 94 healthy elderly regulated air temperature for themselves for 120 minutes. The preferred air temperature were from $24.3^{\circ} \mathrm{C}$ to $29.3^{\circ} \mathrm{C}$. The average of the preferred air temperature was $26.9^{\circ} \mathrm{C}$. There were differences in skin temperature and heat loss by preferred air temperature. The temperature the subjects regulated lower than $25^{\circ} \mathrm{C}$ were thought too cold from the physiological response.
\end{abstract}

Keywords : Elderly, Preferred air temperature, Skin temperature, Thermal Comfort, Thermal sensation, Individual variations 高齢者，好まれる気温，皮膚温，快適感，温冷感，個人差

\section{1. はじめに}

高齢者の体温調節機能に関して多数研究されており、入來 ${ }^{1)}$ や栃 原 ${ }^{2)}$ は高齢者の体温調節の特徴をまとめ、寒冷に対して皮膚血管収 縮や熱産生の開始が遅れ、体内温の低下が大きく、高温に対しては 発汗や皮膚血管拡張の開始の遅れが見られ、体内温の上昇が大きい としている。更に、徳田ら ${ }^{3)}$ や Tochihara ら ${ }^{4)}$ は高齢者の暑さ寒 さの感受性が劣ること、Ohnaka ら ${ }^{5)}$ は寒さに対する感受性の遅れ がみられ、高齢者ほど暑熱暴露後の過冷房、寒冷暴露後の過暖房を 行ないや寸いとし、榎本ら ${ }^{6)}$ は気流により高齢者の稫幹部皮膚温の 低下度が若齢者より大きいとし、環境の変化に応じて皮膚温などの 生理量を快適と言われている範囲に保つ様に冷暖房器具を用いて調 節することが上手く出来なくなると考えられる。しかし、高齢者の 快適な室内温熱環境に関しては、P.O.Fanger ${ }^{7)}$ やF.H.Rohles $ら^{8)}$ 、 K.J.Collins $ら^{9)}$ などにより、実験室での実験では、高齢者の好む 室温は若齢者の好む室温と差はないとしたが、実生活では、高齢者 の方が低い室温で生活しているなど、配慮する必要性があると言わ れている。10）日本では川島ら 11１2）により高齢者の季節に応じた快 適温湿度範囲が提案されている。しかし、老化による機能低下は個 人による差が大きく $\left.{ }^{13}\right)$ なるともいわれており、個人差が少ないと 考えられる若齢者においても、ちょうど良いとする気温には季節を 問わず約 $7{ }^{\circ} \mathrm{C}$ の差 ${ }^{14)}{ }^{15)}$ が認められており、個人差が大きいと考え られる高齢者を画一化してとらえて提案された環境にいても、快適
と感じる高齢者ばかりではないと考えられる。高齢者の好む気温に 関しては、K.J.Collins ら 16) やOhnaka ら ${ }^{5)}$ による室温制御を被 験者自身の手で行い快適温度を検討する実験では、快適温度の最高 温度や最低温度の検討がなされ、平均快適温度は若齢者とほとんど 異ならないが、高齢者の快適温度の個人差は大きく、快適温度範囲 も広いことが示されている。以上からも、画一的に評価した快適温 熱環境の提案のみではなく、高齢者の特性に応じた快適な室内温熱 環境を提案する必要が今後更に増していくと考えられる。

そこで、本報告では佐々ら 14）が実施した若齢者の好む気温の個 人差の検討と同じ実験を実施し、まず高齢者の好む気温の個人差お よび好む気温別の生理心理反応の特徵を把握することを目的として、 実験を実施した。

\section{2. 方法}

\section{2-1 実験室}

実験室内の気温操作ボタンを押すことにより気温を自由に調節す ることができる奈良女子大学環境調節室（W3.0×H2.3×D4.0m）に て実施した。気温は室外の操作盤によっても室内の設定器によって も調節可能である。気流は全面床吹き出し、全面天井吸い込み方式 である。なお、被験者には直接風が当たらない様に絨廹を敷いた。

\section{2-2 実験条件}

温熱環境条件として、気温は気温調節前を $28^{\circ} \mathrm{C}$ と、気温調節を

\footnotetext{
* 武庫川女子大学生活環境学部生活環境学科 講師 ·学博

***奈良女子大学生活環境学部 准教授·学博

*** 奈良女子大学生活環境学部 名誉教授 $\cdot$ 工博

Lecturer, The School of Human Environmental Science, Mukogawa Women’s University, Ph. D.

Assoc. Prof., Faculty of Human Life and Environment, Nara Women's University, Ph. D. Prof., Faculty of Human Life and Environment, Nara Women's University, Dr. Eng.
} 
許可した以後は、被験者自身が自由にちょうど良いように調節した。 周囲壁面温度は気温とほぼ等しいとし、相対湿度 50\%一定、気流速 度は $0.15 \mathrm{~m} / \mathrm{s}$ 以下の不感気流とした。人体側条件として、被験者は 健康な高齢者男女 94 名を採用した。また、既往研究 17) を参考に夏 期の標準的な服装を想定し、着衣量（女性 : $\mathrm{T}$ シャツ、スカート、 ストッキング、パンティ、ブラジャー、男性 : T シャツ、半ズボン、 靴下、下着）は $\left.0.4 \mathrm{clo}^{18}\right) 19 ）$ とした。実験中は椅座安静状態を保ち リラックスしてもらった。

\section{2-3 測定項目および測定方法}

気温は床上 $10 \mathrm{~cm} 、 60 \mathrm{~cm} 、 110 \mathrm{~cm}$ において、湿球温度と黒球温度 は床上 $60 \mathrm{~cm}$ において、 $0.1 \mathrm{~mm} \phi$ の熱電対を用い多点温度計にて測 定した。気流速度は被験者の位置において熱線風速計を用いて測定 した。皮膚温は Hardy\&DuBoisによる 12 点 20) に $0.1 \mathrm{~mm} \phi$ の熱電 対を、サージカルテープを用いて測定部に貼り多点温度計にて測定 した。舌下温は婦人体温計を用いて測定し、体重減少量は体重計を 用い実験開始前と実験終了時の 2 回測定し、その差から算出した。 申告は、快適感 (SD 法 7 段階) および温冷感 ( SD 法 9 段階)、室 温評価などとした。図 1 に実験手順を示す。被験者は設定された人 工気候室に入室し、設定着衣を着用した後、実験装置を装着し、椅 座安静を保ち約 30 分間暴露した後、室内の設定器を用いて 120 分 間気温を「ちょうど良い」と感じる様に被験者自身が好きな時に好 きなだけ自由に気温を調節した。気温は、設定器のボタンを 1 回押 すと $0.5^{\circ} \mathrm{C} \pm 0.2^{\circ} \mathrm{C}$ の精度で変化し、約 10 分で目標温度にて黒球温 度もほぼ安定した。尚、被験者には気温調節操作ボタンを 1 回押寸 と何 ${ }^{\circ} \mathrm{C}$ 気温が变化するかは知らせなかった。皮膚温および気温は 30 秒間隔、申告は 10 分間隔にて測定を行った。

実験は、2003 年および 2005 年、2006 年、2007 年の夏期に実施 した。また、得られた測定值をSPSS を用い分散分析を行った。

\section{2-4 被験者の特徵}

表 1 に高齢者の被験者の特徵を示寸。被験者の身体的特徵は実験 年度が異なってもほぼ同じであった。平均年齢は男性も女性もほぼ 同じであり、身長および体重、体表面積、体格指数は男性の方が大 きかったが、体脂肪率は女性の方が多かった。また、70 歳の全国平 均 21）と比較すると本報告の方が、若干体格が良かった。

\section{3. 結果および考察}

\section{3-1 気温}

\section{（1）気温調節の経時変動例}

図 2 に気温調節の経時変動の例を示す。気温を上昇させるのみの 被験者や気温を下降させるのみの被験者、あるいは全く気温を調節 しない者や気温を上下させる被験者など様々であったが、気温調節 を許可した後、多くの被験者は気温調節をし始めていた。 K.J.Collins ら 16) による、室温が一定勾配で上下寸る人工気候室に て、0.8cloの衣服を着用して寒さを感じたら室温を上げる方向にス イッチを倒し、逆に暑さを感じたら室温を下げる方向に倒して被験 者自ら室温制御を行う実験では、高齢者は快適とする温度範囲は広 く、温度変化を識別する能力が低下しており、大中 ${ }^{2} 2$ ) も同様の実 験を実施し同傾向を示していた。また、Natsumeら 23)による自己 選択による快適温の調節では、若齢者は快適域に達すると気温調節 は認められないが高齢者は快適域に達した後も気温調節が見られて

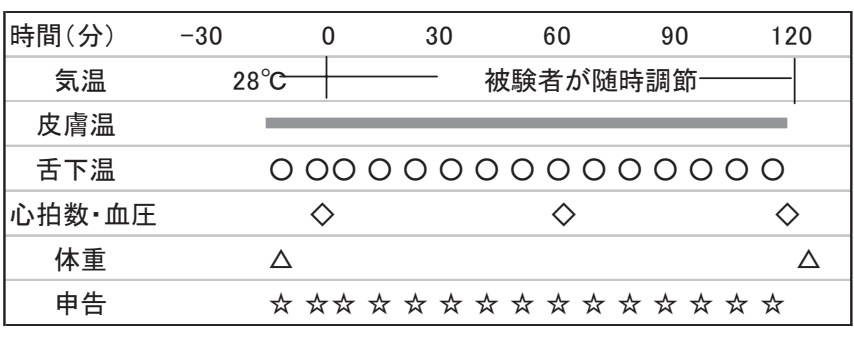

図 1 実験手順

表 1 被験者の身体的特徵

\begin{tabular}{|c|c|c|c|c|c|c|c|}
\hline & $\begin{array}{l}\text { 年齢 } \\
\text { (歳) }\end{array}$ & 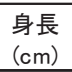 & $\begin{array}{l}\text { 体重 } \\
(\mathrm{kg})\end{array}$ & $\begin{array}{c}\text { 体表面積 } \\
\left(\mathrm{m}^{2}\right)\end{array}$ & $\begin{array}{c}\text { 体格指数 } \\
\left(\mathrm{kg} / \mathrm{m}^{2}\right)\end{array}$ & $\begin{array}{c}\text { 体脂肪率 } \\
(\%)\end{array}$ \\
\hline \multirow{2}{*}{$\begin{array}{c}\text { 女性 } \\
(n=63)\end{array}$} & 平均値 & 70.4 & 150.4 & 52.7 & 1.47 & 23.3 & 32.7 \\
\hline & 標準偏差 & 3.8 & 5.4 & 8.3 & 0.11 & 3.1 & 5.3 \\
\hline \multirow{2}{*}{$\begin{array}{c}\text { 男性 } \\
(n=31)\end{array}$} & 平均値 & 71.8 & 162.7 & 59.9 & 1.64 & 22.8 & 25.5 \\
\hline & 標準偏差 & 5.5 & 5.4 & 8.9 & 0.10 & 3.4 & 4.9 \\
\hline \multirow{2}{*}{$\begin{array}{c}\text { 全体 } \\
(n=94)\end{array}$} & 平均値 & 70.9 & 154.5 & 55.1 & 1.53 & 23.1 & 30.6 \\
\hline & 標準偏差 & 4.5 & 7.9 & 9.1 & 0.13 & 3.2 & 6.1 \\
\hline \multirow{2}{*}{$\begin{array}{l}\text { 全国 } \\
\text { 平均 }\end{array}$} & 女性 & 70 & 146.3 & 50.1 & 1.42 & 23.4 & \\
\hline & 男性 & 70 & 160.1 & 59.0 & 1.61 & 23.0 & \\
\hline
\end{tabular}

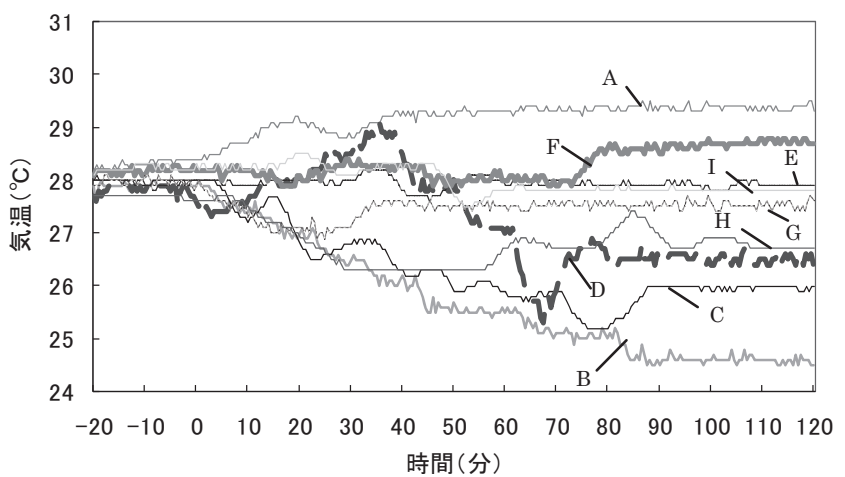

図 2 気温調節の経時変動例

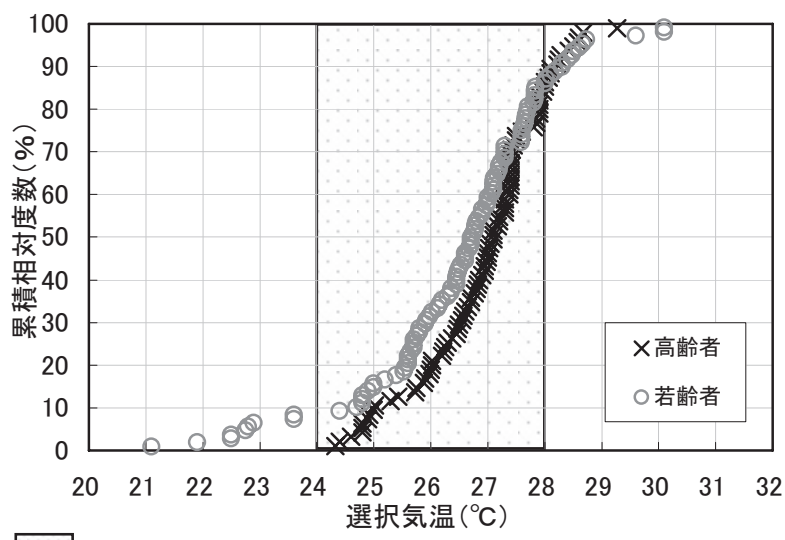

日本建築学会高齢者熱環境研究会による住宅熱環境評価基準值' 91 改定

図3 年代別の選択気温の分布

いたが、本結果では、広い気温範囲内にて気温を上下させる様な被 験者毎の気温変動の幅より個人差の方が大きく認められた。

また、既報の若齢女性の結果 $\left.{ }^{14}\right)$ と同様に気温調節開始より 120 分経過後の気温を好む気温とし、以後「選択気温」として称すこと とする。

\section{（2）好む気温の分布}

図 3 に選択気温の分布を、既往の若齢男女 24)25)26) との結果とあわ せた年代別に示す。図に示寸範囲は 1991 年に日本建築学会高齢者 熱環境研究会により作成された住宅熱環境評価基準值 $\left.\left(25 \pm 2^{\circ} \mathrm{C}\right) 12\right)$ 
である。高齢者の選択気温は $24.3^{\circ} \mathrm{C} \sim 29.3^{\circ} \mathrm{C}$ の範囲であり、約 5 割 の高齢者の選択気温はこの基準值 $\left.{ }^{12}\right)$ 上り高い側であった。若齢者の 選択気温は $21.1^{\circ} \mathrm{C} \sim 30.1^{\circ} \mathrm{C}$ 範囲であり、高齢者の方が個人差は小 さく、ちょうど良い範囲が若齢者より狭かった。これは、K.J.Collins ら 16) による室温制御を被験者自身の手で行い快適温度を検討する 実験では、若齢者に比べ制御回数が少なくなっていた事と同様に、 高齢者の方が、温熱感覚が鈍くなっておりその環境を良いと考えあ まり気温調節しない傾向にある事が考えられる。年代別に平均寸る と、高齢者は $26.9 \pm 1.1^{\circ} \mathrm{C}$ 、若齢者は $26.5 \pm 1.6^{\circ} \mathrm{C}$ であり、平均選択 気温は高齢者の方が高く、有意差が認められた。ASHRAE 27)では夏 期は作用温度約 $23 \sim 27^{\circ} \mathrm{C}$ であることと、既往の着衣量 0.6clo での 高齢者の快適気温は Fanger7) ${ }^{28)}$ は $25.7^{\circ} \mathrm{C}$ おび $25.4^{\circ} \mathrm{C}$ や Rohles and Johson ${ }^{8}$ は $24.5^{\circ} \mathrm{C}$ である。また、住宅熱環境評価基準值 ${ }^{12)}$ の中 央值は $25^{\circ} \mathrm{C}$ であり、 $\mathrm{SET}^{*}$ に換算すると $23.6^{\circ} \mathrm{C}$ となり、同様に本実 験での高齢者の平均選択気温は $\mathrm{SET}^{*} 25.8^{\circ} \mathrm{C}$ となり、 $2.2^{\circ} \mathrm{C}$ 高くなつ ていた。

\section{3-2 性差}

\section{（1）性別の好む気温の分布}

図 4 に選択気温の分布を性別に示す。性別では、高齢男性の選択 気温は $24.8^{\circ} \mathrm{C} \sim 28.5^{\circ} \mathrm{C}$ 範囲、個人差は $3.7^{\circ} \mathrm{C}$ 、平均すると $26.7 \pm$ $1.0^{\circ} \mathrm{C}$ であった。高齢女性の選択気温は $24.3^{\circ} \mathrm{C} \sim 29.3^{\circ} \mathrm{C}$ の範囲、個 人差は $5.0^{\circ} \mathrm{C}$ 、平均すると $27.0 \pm 1.1^{\circ} \mathrm{C}$ であり、個人差は高齢男性の 方が高齢女性より小さく、平均選択気温では有意差は認められなか ったが高齢男性の方が若干低かった。前述の住宅熱環境評価基準值 $\left(25 \pm 2^{\circ} \mathrm{C}\right){ }^{12)}$ の上限の $27^{\circ} \mathrm{C}$ より高く調節したのは女性では約 6 割 が、男性では約 5 割であり、女性の方がその割合は高かった。

\section{（2）選択気温と平均皮膚温の関係}

図 5 に高齢者の選択気温と平均皮膚温の関係を性別に示す。男性 も女性も気温の影響を受け、気温が低いと平均皮膚温も低く、気温 が高いと平均皮膚温も高くなる傾向を示した。男性の方が女性より、 低い選択気温において平均皮膚温が若干低くなる傾向を示したが、 選択気温時の平均皮膚温は、女性は $33.9^{\circ} \mathrm{C} \pm 0.5^{\circ} \mathrm{C}$ 、男性は $33.7^{\circ} \mathrm{C}$ $\pm 0.5^{\circ} \mathrm{C}$ でありほぼ同じであった。既往の研究では快適な平均皮膚温 は磯田ら ${ }^{29)}$ は $33^{\circ} \mathrm{C}$ や志村ら ${ }^{30}$ ) $33^{\circ} \mathrm{C} \sim 34^{\circ} \mathrm{C} 、$ P.O.Fanger ${ }^{31}$ ) は、裸 体でも着衣でも平均皮膚温度は $33 \sim 34^{\circ} \mathrm{C}$ で発汗のない状態とし、こ の範囲から高齢者の約 4 割が外れていた。

\section{（3）温冷感と快適感の関係}

図 6 に選択気温時の温冷感と快適感の関係を性別に示す。選択気 温および性別に関わらず、多くが温冷感は「涼しい」〜「どちらで もない」の範囲であり、最も「やや涼しい」で「快適」とする割合 が高く、多くの被験者は「涼しい」側となるように気温調節をした と考えられる。これは、同様の若齢者の結果 ${ }^{14}$ ) や久保ら 32 )による 夏期は「涼しい」環境を好むこととほぼ同様の結果であった。

\section{3-3 好む気温群別の検討}

以上より、選択気温および平均皮膚温、全身温冷感において性別 には有意な差が認められなかった為、以後は性差を考慮せずに検討 することとした。また、好む気温別の特徴を検討する為に、選択気 温を $1{ }^{\circ} \mathrm{C}$ 範囲毎に分けると、 $24^{\circ} \mathrm{C}$ 台は $9 \% 、 25^{\circ} \mathrm{C}$ 台は $9 \% 、 26^{\circ} \mathrm{C}$ 台は $24 \% 、 27^{\circ} \mathrm{C}$ 台は $43 \% 、 28^{\circ} \mathrm{C}$ 台は $15 \% 、 29^{\circ} \mathrm{C}$ 台は $1 \%$ となった。以後 の検討では、 $24^{\circ} \mathrm{C}$ 台 $27^{\circ} \mathrm{C}$ 台をそれぞれ $24^{\circ} \mathrm{C} \sim 27^{\circ} \mathrm{C}$ と表記し、 $28^{\circ} \mathrm{C}$

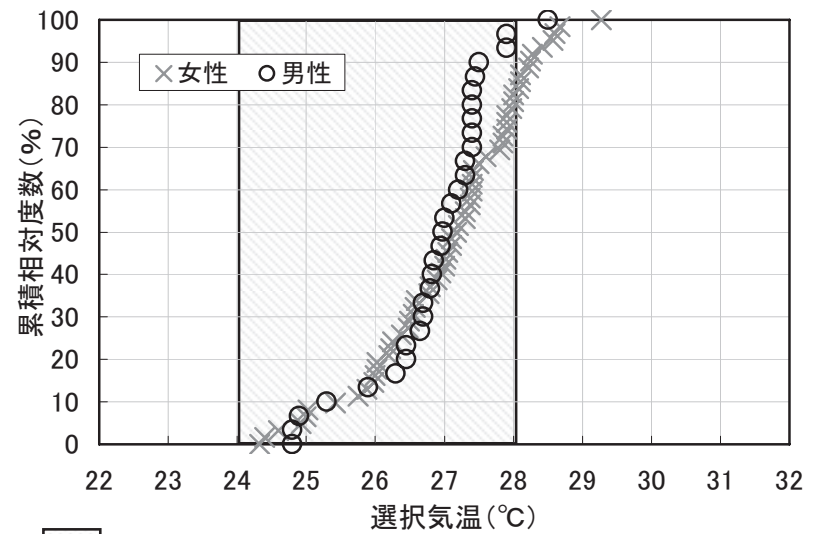

日本建築学会高齢者熱環境研究会による住宅熱環境評価基準值' 91 改定 図 4 性別の選択気温の分布

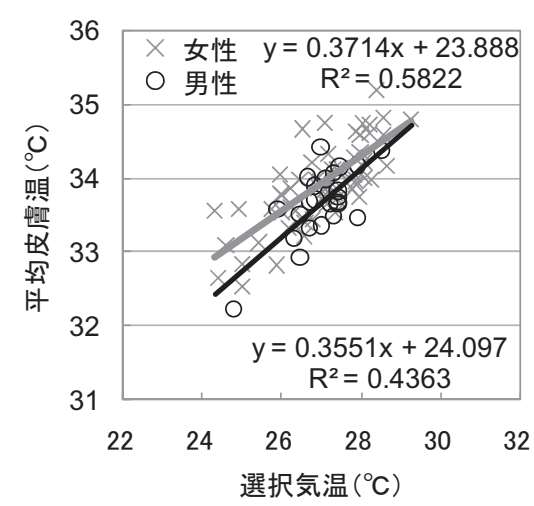

図 5 性別の選択気温と平均皮膚温の関係

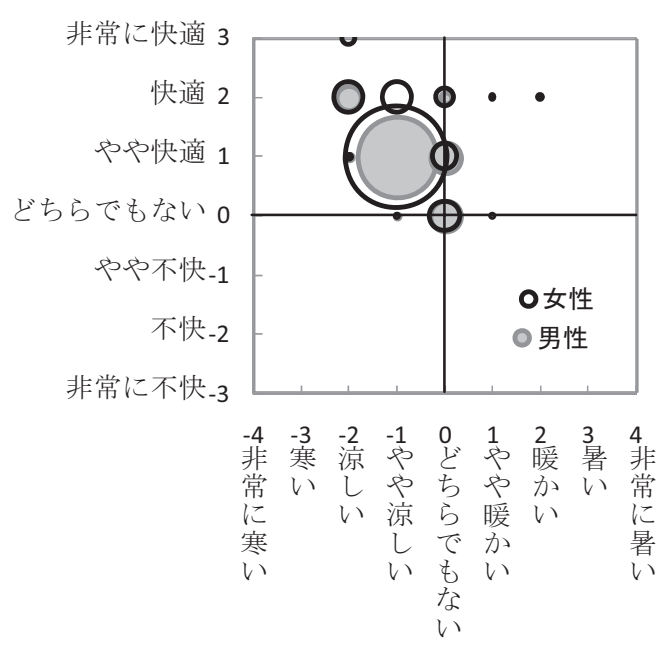

図 6 性別の全身温冷感之快適感の関係

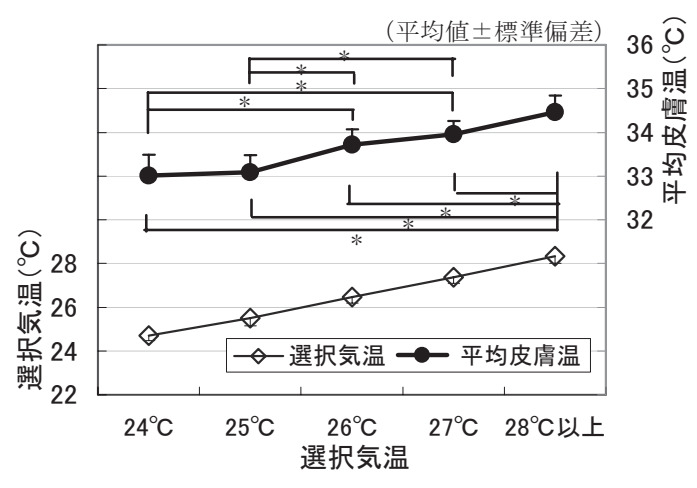

注）有意差検定 * : $\mathrm{p}<0.05$

図 7 選択気温と平均皮膚温 

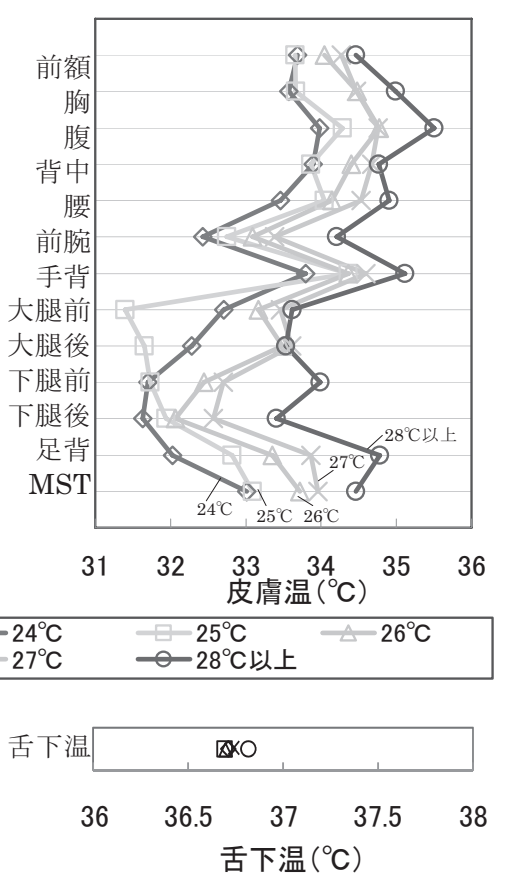

図 8 部位別皮膚温および舌下温の分布
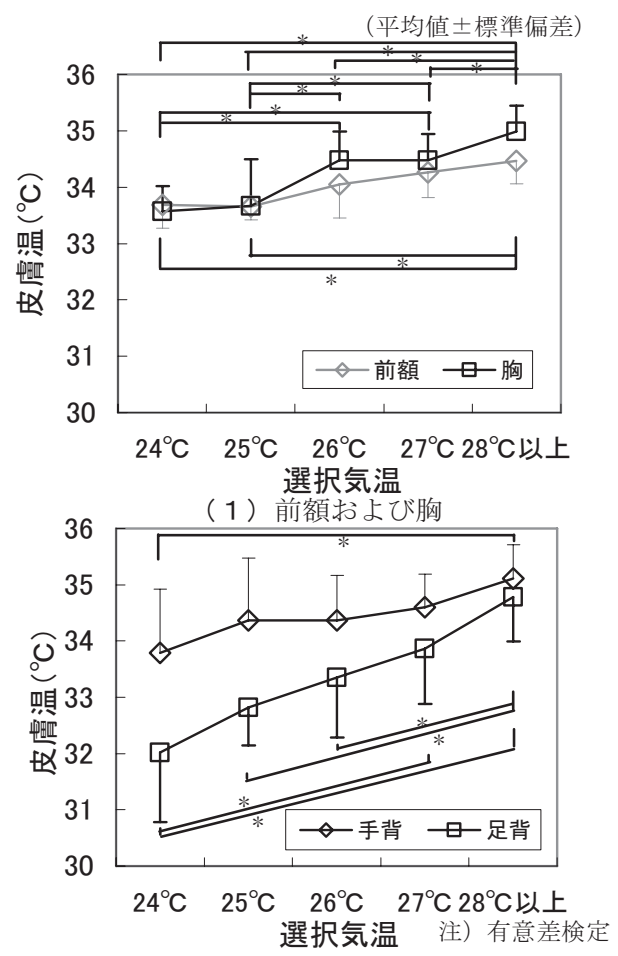

（2）手背および足背 * $\mathrm{p}<0.05$

図 9 躯幹部および末梢部皮膚温

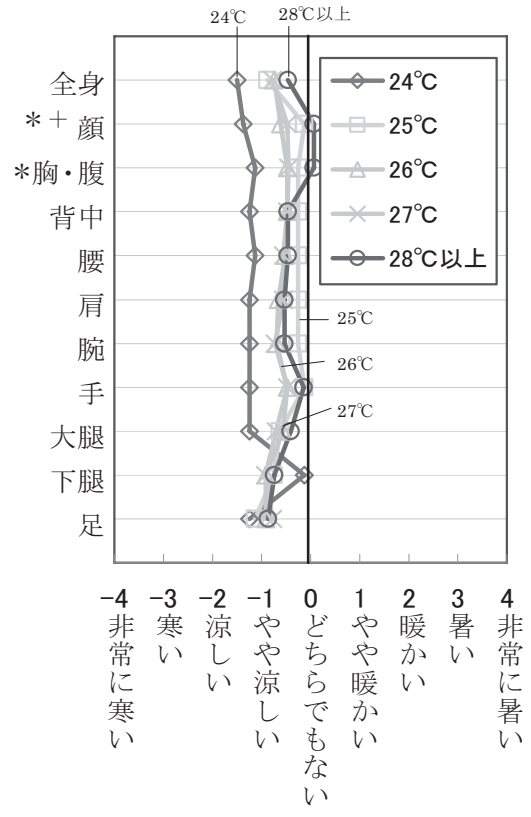

注）有意差検定

$24^{\circ} \mathrm{C}$ と $28^{\circ} \mathrm{C}$ の有意差検定 * : $\mathrm{p}<0.05$ $24^{\circ} \mathrm{C}$ と $25^{\circ} \mathrm{C}$ の有意差検定 $+: \mathrm{p}<0.05$

図 10 部位別温冷感の分布
台と $29^{\circ} \mathrm{C}$ 台を併せて $28^{\circ} \mathrm{C}$ 以上とすることとした。

\section{（1）選択気温と平均皮膚温}

図 7 に選択気温と平均皮膚温を選択気温群別の平均值と標準偏差 で示す。各選択気温群の平均選択気温は、 $24^{\circ} \mathrm{C}$ は $24.7^{\circ} \mathrm{C} 、 25^{\circ} \mathrm{C}$ $25.5^{\circ} \mathrm{C} 、 26^{\circ} \mathrm{C} 26.5^{\circ} \mathrm{C} 、 27^{\circ} \mathrm{C} 27.4^{\circ} \mathrm{C} 、 28^{\circ} \mathrm{C}$ 以は $28.3^{\circ} \mathrm{C}$ であり、 平均選択気温は各選択気温群間全てに有意差が認められた。平均皮 膚温は、選択気温が高いと平均皮膚温も高い傾向を示したが、 $24^{\circ} \mathrm{C}$ と $25^{\circ} \mathrm{C}$ の間および $26^{\circ} \mathrm{C}$ と $27^{\circ} \mathrm{C}$ の間では各々平均選択気温には約 $1^{\circ} \mathrm{C}$ の有意な差が認められたが、平均皮膚温はそれぞれ約 $33^{\circ} \mathrm{C}$ よ び約 $34^{\circ} \mathrm{C}$ とほぼ同じであり有意な差は認められなかった。これは、 $26^{\circ} \mathrm{C}$ およ゙ $27^{\circ} \mathrm{C}$ は血流調節領域であったためと考えられる。 $28^{\circ} \mathrm{C}$ 以上では $34.5^{\circ} \mathrm{C}$ となり、他の選択気温群と有意差が認められ、高い 気温に調節した被験者の多くは平均皮膚温が高くなり、気温の影響

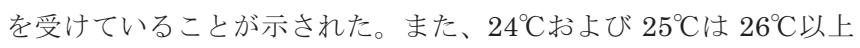
の選択気温群より有意に低くなっていた。

\section{（2）部位別皮膚温の分布}

図 8 に選択気温時の部位別皮膚温および舌下温の分布を選択気温 群別の平均值で示す。選択気温が高いと各部位の皮膚温は高く、選 択気温が低いと各部位の皮膚温は低くなる傾向を示し、脚部の皮膚 温において選択気温群による差が大きかった。 $24^{\circ} \mathrm{C}$ と $25^{\circ} \mathrm{C}$ 間、お よび $26^{\circ} \mathrm{C}$ と $27^{\circ} \mathrm{C}$ の間は同傾向となる部位が多かった。また、気温 が低い方が各部位の温度差が大きく、気温が高い方が各部位の温度 差が小さい傾向を示し、選択気温により皮膚温の分布は異なってい た。舌下温は $28^{\circ} \mathrm{C}$ 以上が他群よりやや高くなったが、有意な差は認 められなかった。

図 9 に躯幹部の代表として前額および胸を、未梢部の代表として 手背および足背の皮膚温を選択気温群別の平均值および標準偏差に て示す。選択気温群により皮膚温は異なり、前額および胸は気温が
低いほど皮膚温も低くなり、低い選択気温群と高い選択気温群では 有意な差が認められた。手背は選択気温群による差は小さかったが、 足背は $24^{\circ} \mathrm{C}$ と $27^{\circ} \mathrm{C}$ およ゙ $28^{\circ} \mathrm{C}$ 以上と、 $28^{\circ} \mathrm{C}$ 以上と $24^{\circ} \mathrm{C} \sim 26^{\circ} \mathrm{C}$ ま での間に有意差が認められた。佐々ら $\left.{ }^{15}\right)$ の若齢女性の気温 $24^{\circ} \mathrm{C}$ 下 での皮膚温分布と比較すると、高齢者の躯幹部の皮膚温は低く、未 梢部の皮膚温は高い傾向を示し、高齢者の体温調節能力の低下が認 められた。これらは、榎本ら ${ }^{6)}$ による各部位の皮膚温の差が若齢者 と比較して小さくなっている傾向を示したことや、都築 ${ }^{33}$ による 気温が同じで着衣量が多くても高齢者の方が手背皮膚温は低いこと や渡辺ら ${ }^{34)}$ による高齢者は青年者より躯幹部皮膚温は低温であり、 逆に四肢部は $23^{\circ} \mathrm{C}$ 下において高齢者は高いことと同様であった。特 に $24^{\circ} \mathrm{C} 、 25^{\circ} \mathrm{C}$ において躯幹部の皮膚温の低さおよび末梢部の皮膚温 の高さが認められた事は、放熱過多の恐れが考えられる。

\section{（）部位別温冷感の分布}

図 10 に選択気温時の部位別温冷感の分布を選択気温群別の平均 值で示す。各部位の温冷感は、 $24^{\circ} \mathrm{C}$ にいて他群より涼しい側が多 く、顔および胸・腹に有意差は認められたが、選択気温に関わらず ほぼ「やや涼しい」〜「どちらでもない」の範囲であり有意差は認 められなかった。前述の部位の皮膚温分布は選択気温群別に異なり、 特に脚部の差が大きかったが、温冷感には差が認められなかった。 これは、徳田ら ${ }^{3)}$ や Tochihara ら ${ }^{4)}$ と同様に加齢による温冷感覚 の鈍化とも考えられる。また、高齢者の足部の冷点が若年者と比べ 約半分まで減少となることが報告 ${ }^{35)}$ されており、この点との関係 も検討する必要がある。

\section{(4) 放熱量}

今後の課題として概略を検討する為に、放熱量を求めた。既報 ${ }^{14}$ ) と同様に算出し、「総放熱量」は「水分蒸発放熱量」と「対流十放射 放熱量」との合計で求めた。用いた数值は、体重減少量は実験前後 
の值しか得られなかった為、その差から求め、気温 および皮膚温は選択気温時の值を用いて算出した。

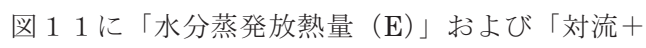
放射放熱量 $(\mathrm{R}+\mathrm{C}) 」 、 「$ 総放熱 $(\mathrm{E}+\mathrm{R}+\mathrm{C}) 」$ を選択気 温群別の平均值および標準偏差で示す。「水分蒸発放 熱量」は選択気温群別に有意差は認められなかった。 「対流十放射放熱量」は気温の影響を受け、気温が 低いと多く、逆に気温が高いと少ない傾向を示し、 選択気温群別に有意差が認められた。「総放熱量」も 同様に気温の影響を受け、気温が低いと多く気温が 高いと少ない傾向を示し、平均すると $24^{\circ} \mathrm{C}$ では $64 \mathrm{~W} / \mathrm{m}^{2} 、 25^{\circ} \mathrm{C}$ では $58 \mathrm{~W} / \mathrm{m}^{2} 、 26^{\circ} \mathrm{C}$ では $56 \mathrm{~W} / \mathrm{m}^{2} 、$ $27^{\circ} \mathrm{C}$ では $54 \mathrm{~W} / \mathrm{m}^{2} 、 28^{\circ} \mathrm{C}$ 以上では $50 \mathrm{~W} / \mathrm{m}^{2}$ であり、 $28^{\circ} \mathrm{C}$ 以上と $24^{\circ} \mathrm{C} \sim 26^{\circ} \mathrm{C}$ と、 $24^{\circ} \mathrm{C}$ と $27^{\circ} \mathrm{C}$ 間に有意差が認められた。 既報の若齢女性を対象とした選択気温実験 $\left.{ }^{14}\right)$ では、 $25^{\circ} \mathrm{C}$ より低い 気温に調節した低温群では $59 \mathrm{~W} / \mathrm{m}^{2} 、 27 \pm 2^{\circ} \mathrm{C} の$ 範囲に調節した中 温群では $49 \mathrm{~W} / \mathrm{m}^{2}$ であり、ほぼ同様の選択気温であっても高齢者の 方が放熱量は多かった。また、舌下温は気温調節前と選択気温時と 比較すると、 $24^{\circ} \mathrm{C}$ では $0.29^{\circ} \mathrm{C}$ 低下しており、実生活では長時間自身 が調節した環境に滞在すると考えると、高齢者の放熱過多が緐念さ れる。また、Fanger 7) は高齢者と若齢者の快適な気温には差がない とする理由として、高年者は一般に若年者よりも代謝量は低いもの の、それにみあって蒸泄量も低く、産熱と放熱の均衡がとれ、高齢 者の快適温が若年者よりも高くなることはないとしたが、本結果で は $24^{\circ} \mathrm{C}$ の選択気温群では高齢者の放熱過多が懸念される。

\section{(5) 血圧の分布}

図 12 に気温調節前および選択気温時の血圧を選択気温群別の平 均值および標準偏差で示す。気温調節前後で大きな差は認められず、 ほぼ同様であった。また、選択気温時の最高血圧および最低血圧は 選択気温群別に有意な差は認められなかった。

\section{3-4 好む気温群別の特徵}

以上より、好む気温群別に、皮膚温の分布は異なっていたが、部 位の温泠感は $24^{\circ} \mathrm{C}$ の他群よりやや涼しい側であるが、 $25^{\circ} \mathrm{C}$ 以上は ほぼ同じ温冷感を示していた。特に脚部の皮膚温は最も選択気温群 別に差が認められていたが、いずれも温冷感はほぼ同じであった。 $24^{\circ} \mathrm{C}$ と $25^{\circ} \mathrm{C}$ の間、および $26^{\circ} \mathrm{C}$ と $27^{\circ} \mathrm{C}$ の間は、皮膚温は同様の傾向 を示していた。また、 $24^{\circ} \mathrm{C}$ と $25^{\circ} \mathrm{C}$ は、 $26^{\circ} \mathrm{C}$ 以上の選択気温群と比 心、平均皮膚温は有意に低く、部位では躯幹部の皮膚温の低さおよ び末梢部の皮膚温の高さが認められ、放熱過多の恐れが考えられる。 これらの事より、特に $24^{\circ} \mathrm{C}$ 選択気温群は、調節した気温が低すぎ ると考えられる。

\section{4. まとめ}

夏期における高齢者の好む気温の個人差および好む気温別の生 理心理反応の特徴を検討した結果、以下の様にまとめられる。

1 ) 高齢者の好む気温は、「やや涼しい」〜「どちらでもない」と感 じる時であり、選択気温は $24.3^{\circ} \mathrm{C} \sim 29.3^{\circ} \mathrm{C}$ 範囲であり、約 5 割 の高齢者の選択気温は住宅熱環境評価基準值 $\left(25 \pm 2^{\circ} \mathrm{C}\right)$ 2) より高 い側であった。

2 ) 高齢者の平均選択気温は $26.9 \pm 1.1^{\circ} \mathrm{C}$ であり、若齢者より高く、
(平均值士標準偏差)

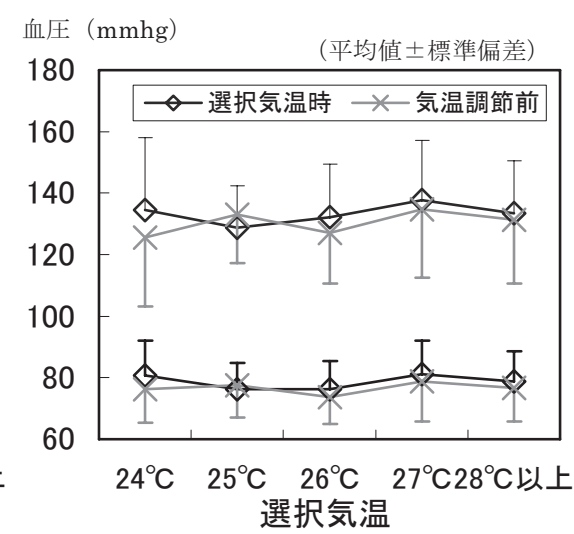

図 12 最高血圧および最低血圧

個人差が小さかった。

3 ）性別では、男性の方が女性より選択気温の範囲は狭かったが、 性別の平均選択気温、平均皮膚温および全身温冷感には有意な差 は認められなかった。

4 ）選択気温群別に、平均皮膚温は有意に異なり、部位の皮膚温差 は大きく、躯幹部および末梢部の皮膚温に差が認められ、低い気 温に調節した被験者の躯幹部皮膚温の低さおよび末梢部皮膚温の 高さが示され、放熱過多の恐れが考えられた。

5 ) 放熱量は、 $24^{\circ} \mathrm{C}$ の選択気温群に放熱過多の傾向が示された。

6 ) 選択気温群別に、部位別温冷感は、躯幹部に差が認められたが、 多くは選択気温に関わらずほぼ「やや涼しい」〜「どちらでもな い」の範囲であり、特に足部はほぼ同じ温冷感である傾向が認め られた。

7 ) 好ましい温度としては、 $25^{\circ} \mathrm{C}$ 以下に調節することは望ましくな い事が示された。

今後は更に、好む気温と高齢者の温熱的特性の関係に関して詳細に 検討する予定である。

\section{謝辞}

ご協力頂きました被験者の方々に深く感謝の意を表します。また、 本研究を遂行するにあたり、多大なる協力を得た衣笠奈々恵さん、 寺田留美さん（当時、奈良女子大学院生）、中田知佳さん、松野美咲 さん、上野明日香さん、川越絵美さん（当時、武庫川女子大学）に 深謝を表します。本研究の一部は、財団法人 住宅総合財団の助成 を受け実施した。

\section{参考文献}

1) 入來正躬 : 体温生理学テキスト、pp. 146-248、文光堂、2003

2) 栃原裕：快適温度と加齢、The Annals of physiological anthropology, 4(1), pp. $87-90,1985$

3）徳田哲男、他: 環境温度の変化と高齢者の心身諸機能に関する研究、人間 工学、25(4)、pp. 197-206、1989

4) Tochihara,Y. et al: Physiological responses and thermal sensations of the elderly in cold and hot environments, J.Therm.Biol., 18, pp.355-361, 1993

5) Tadakatsu Ohnaka, Yudaka Tochihara, et.al : Preferred Temperature of the elderly after cold and heat exposures determined by individual self-selection of air temperature, J.therm.Biol. Vol.18, No.5/6, pp.349-353, 1993

6）榎本ヒカル、他：高齢者の夏期における選択気流速度に関する研究、空気 調和・衛生工学、56、pp. 69-76、1994

7) P.O.Fanger:Thermal comfort, pp.75-86, McGraw-Hill Book Company, New 
York.,1970

8 ) F.H.Rohles,Jr, M.A.Johnson:Thermal Comfort in the Elderly, ASHRAETransactions, pp.131-137, 1972

9 ) K.J.Collins:Hypothermia and Thermal Responsiveness in the Elderly, 819-833,Danish Building Research Institute, 1979

10) 2005 ASHRAE Handbook Fundamentals, CHAPTER 8 Thermal Comfort, 8.15

11）川島美勝、後藤滋、大平通泰：住宅熱環境の調査と評価法（4）環境体 温計の開発と住宅熱環境法、第 7 回人間-熱環境系シンポジウム報告集、 pp. 104-107、1983. 12

12）川島美勝 編著 : 高龄者の住宅熱環境、p239、理工学社、1994

13）川島美勝 編著 : 高齢者の住宅熱環境、p56、p72、理工学社、1994

14）佐々尚美、他：夏期における好まれる気温の個人差に関する研究、日本 建築学会計画系論文集、第 531 号、pp. 31-35、2000.5

15）佐々尚美、他：冬期における好まれる気温に関する研究、日本建築学会 計画系論文集、第 541 号、pp. 17-22、2001.3

16) K.J.Collins, A.N.Exton-Smith, Caroline Dore : Urban hypothermia:Preferred temperature and thermal perception in old age,British Medical Journal, Vol.282,pp.175-177,1981

17）榎本ヒカル、久保博子、磯田憲生、梁瀬度子、高齡者の居住温熱環境の 特徵一関西地区における夏期および冬期の住まい方に関する調査研究一、 日本家政学会誌、Vo1.46 No. 11、pp. 1091-1100、1995

18）花田、他：婦人用下着類の熱抵抗の計測に関する研究、繊維製品消費科 学、vol. 22, No, 10、pp. 34-41、1981

19）磯田憲生：生活と衣服に関寸る一考察、衣生活研究、No. 6、pp. 15-20、 1980

20) J,D,Hargy et al. : The technic of measuring radiation and convection,Journal of Nutrition,15,pp.461-475,1987

21）国立天文台編：理科年表、丸善株式会社、p819、2005

22）大中忠勝：高齢者の住宅熱環境、理工学社、pp. 128-142、1994

23) Natsume K, Ogawa T, Ohnishi $\mathrm{N}$ et al: Preferred ambient temperature for old and young men in summer and winter, International journal of biometeorology, 36, pp.1-4,1992

24）水田、他：至適温熱環境の個人差に関する研究一夏期と冬期における好 ましい気温の比較一、第 30 回人間-生活環境系シンポジウム報告集、 pp. 97-100、2006

25）水田、他：夏期における至適温熱環境の個人差に関する研究 異なる気 温下での生理・心理反応の男女差について、社団法人日本化成学会第 59 会 大会 研究発表要旨集、p. 221、2007

26）水田、他：夏期における至適温熱環境に関する研究-異なる気温下での生 理・心理反応の性差について- 空気調和・衛生工学会大会学術講演論文集、 pp. 1271-1274、2007

27) ASHRAE 2005 Fundamentals, Chapter 8, 2005

28) P.O.Fanger: Assessment of man's thermal comfort in practice, British Journal of Industrial Medicine, 30, pp.313-324, 1973

29) 磯田憲生、他：風洞内気流と人体皮膚温との関係に関する実験的研究、日 本建築学会論文報告集、第 229 号、pp. 121-128、1975.3

30)志村欣一、他：日本人を対象とした室内温湿度条件の至適域に関する実験 研究-夏季至適域の提案-, 日本建築学会計画系論文集、第 480 号、pp. 15-24、 1996. 2

31) P.O.Fanger: Assessment of man's thermal comfort in practice, British Journal of Industrial Medicine, 30, pp.313-324, 1973

32）久保博子 他：温冷感と快適感の季節差に関する実験的研究、人間と生 活環境、第 1 巻第 1 号、pp. 51-57、1994

33) 都築和代 : 高蹂者の温熱感覚特性に関する簡易温冷覚刺激装置を用いた検 討、人間と生活環境、第 2 巻第 1 号、pp. 43-47、1995

34）渡辺ミチ、他：女子高齢者における体温調節反応、家政学会誌、32（3）、 pp. 204-209、1981

35) 村田成子、他田: 老人の体温 - 皮膚感覚点分布頻度に及ぼす加齢の影響、 pp. 100、2005、日本老年医学会雑誌 11(3)、 pp. 157-163、1974

注

注 1 ）「対流＋放射放熱量」は以下の式を用いた。また、本研究では気温と 周囲壁面温度が等しいので、 $\mathrm{To}=\mathrm{Ta}$ とした。

$\mathrm{C}+\mathrm{R}=\mathrm{h} /(1+0.155 \mathrm{~h} \cdot \mathrm{Iclo}) \times(\mathrm{Ts}-\mathrm{To})$

$\mathrm{h}=\mathrm{hr}+\mathrm{hc}$

$\mathrm{hr}$ : 放射熱伝達率 $(=4.65) \quad\left(\mathrm{W} / \mathrm{m}^{2}{ }^{\circ} \mathrm{C}\right)$ hc：対流熱伝達率 $(=3.7)$

Iclo：衣服の熱抵抗

Ts : 平均皮膚温

To : 作用温度 $(=\mathrm{Ta}$ : 気温 $)$

(2010年 1 月 10 日原稿受理, 2010年 6 月 1 日採用決定） 